\title{
Management Implications of Molt Migration by the Atlantic Flyway Resident Population of Canada Geese, Branta canadensis
}

\author{
Susan E. Sheaffer ${ }^{1,6}$, Richard A. Malecki ${ }^{2,6}$, Bryan L. SwiFT $^{3}$, John DunN $^{4}$, and Kim ScribneR ${ }^{5}$ \\ ${ }^{1}$ Department of Natural Resources, Cornell University, Ithaca, New York 14853 USA \\ ${ }^{2}$ U.S. Geological Survey, New York Cooperative Fish and Wildlife Research Unit, Department of Natural Resources, Cornell \\ University, Ithaca, New York 14853 USA \\ ${ }^{3}$ New York State Department of Environmental Conservation, Bureau of Wildlife, Game Bird Unit, 625 Broadway, Albany, \\ New York 12233 USA \\ ${ }^{4}$ Pennsylvania Game Commission, 911 Big Spring Road, Shippensburg, Pennsylvania 17257 USA \\ ${ }^{5}$ Department of Fisheries and Wildlife, Michigan State University, East Lansing, Michigan 48824 USA \\ ${ }^{6}$ Present address: Livingston Ripley Waterfowl Conservancy, P.O. Box 210, Litchfield, Connecticut 06759 USA
}

Sheaffer, Susan E., Richard A. Malecki, Bryan L. Swift, John Dunn, and Kim Scribner. 2007. Management implications of molt migration by the Atlantic Flyway resident population of Canada Geese, Branta canadensis. Canadian Field-Naturalist 121(3): 313-320.

We used satellite-tracked transmitters in 2001 and 2003 to document the timing, location, and extent of molt migrations by female Canada Geese (Branta canadensis) affiliated with the Atlantic Flyway Resident Population (AFRP) of Canada Geese that breed in the temperate region of eastern North America. Twenty-seven adult females were captured during the nesting period in late May and fitted with a satellite transmitter mounted either on a plastic neck collar or backpack harness. Nests of 24 birds were destroyed late in incubation to prevent renesting and ensure nest failure; three females did not have nests. Twelve of the 27 birds (44\%) made a northward migration to molt in northern Quebec, Canada: seven to the eastern coast of Hudson Bay $\left(58^{\circ} 12^{\prime} \mathrm{N}, 76^{\circ} 60^{\prime} \mathrm{W}\right)$, three to lowland areas east of James Bay $\left(53^{\circ} 30^{\prime} \mathrm{N}, 79^{\circ} 02^{\prime} \mathrm{W}\right)$, and two to interior locations south of Ungava Bay $\left(55^{\circ} 54^{\prime} \mathrm{N}, 68^{\circ} 24^{\prime} \mathrm{W}\right)$. Molt migrants were present in northern Quebec from June to September, a period that coincides with breeding ground aerial surveys and banding operations conducted for Atlantic Population (AP) Canada Geese that breed in this same region of northern Quebec. With $>1$ million AFRP geese estimated in the Atlantic Flyway, the potential exists for substantial numbers of yearling, sub-adult, and nest-failed or non-breeding adults to molt migrate to northern breeding areas and bias efforts to survey and mark AP geese. Within AFRP breeding areas, many local flocks have reached nuisance levels. We hypothesized that by inducing molt migration in breeding adults, through destruction of nests late in incubation, we would lessen recruitment, reduce numbers of summer resident adults with young, and increase adult mortality from hunting. However, molt migration behavior was not uniform throughout our study area. Molt migrants were from rural areas in New York, Pennsylvania, and Vermont, whereas marked birds that did not make molt migrations were from more coastal regions of the flyway. The 14 birds that did not make a molt migration remained within $60 \mathrm{~km}$ of their banding site. A genetic comparison of these two groups revealed no detectable differences. We conclude that failure to undergo a molt migration is likely attributed to the historical origin of captive-reared birds of mixed subspecies that comprise AFRP flocks in the eastern regions of the flyway and the availability of quality local habitat, distinct from brood-rearing areas, for molting.

Key Words: Branta canadensis, Canada Geese, molt migration, temperate-nesting, Resident Population, Atlantic Flyway.

Canada Geese (Branta canadensis) often undergo a late spring migration, flying long distances from their breeding locations to more northerly areas, where they undergo an annual molt. A form of molt migration, these movements have been documented for Canada Geese from both subarctic-nesting populations, which typically breed in remote areas of northern Canada (Sterling and Dzubin 1967; Abraham et al. 1999), and temperate-nesting populations, that breed in southern Canada and the United States (Zicus 1981; Davis et al. 1985; Lawrence et al. 1998). Birds that undergo a molt migration are primarily nonbreeding subadults and unsuccessful breeding adults (Salomonsen 1968; Lawrence et al. 1998).

There are two subarctic-nesting populations (Atlantic Population [AP] and North Atlantic Population [NAP]) associated with the states of the Atlantic Flyway, whereas temperate-nesting geese are collectively recognized as the Atlantic Flyway Resident Population (AFRP; Atlantic Flyway Waterfowl Council 1999*). Because these populations are mostly indistinguishable when they mix in the field on migration routes and wintering locations, their population and harvest management depends on monitoring efforts directed at their population-specific breeding areas. For example, annual assessments of population size are dependent on spring aerial surveys of breeding areas. However, movement of molting groups of temperate-nesting geese from Michigan to subarctic breeding areas in northern Canada has been confirmed through monitoring with satellite-tracked transmitters (Mykut et al. 2004). If molt migrations by temperate-nesting geese occur while spring surveys are being conducted on northern breeding grounds, then population estimates for subarcticnesting populations can be positively biased by the inclusion of molt migrants (Abraham et al. 1999). 
Similarly, population-specific assessments of harvest rely on band recoveries obtained from birds marked on their breeding grounds as flightless adults and young. In recent years, recaptures on subarctic breeding grounds of previously banded adults and young from temperate-nesting areas (Abraham et al. 1999; Nichols et al. 2004) have raised concern over the potential bias in the banded samples of subarctic-nesting geese. Molt migrations of temperate-nesting geese to northern breeding areas can also increase competition for resources and potentially degrade brood-rearing habitat for subarctic-nesting geese. Previous studies have demonstrated that a large proportion $(50 \%-60 \%)$ of temperate-nesting flocks potentially undergo a molt migration (Zicus 1981; Lawrence et al. 1998). Given that estimated numbers of temperate-nesting geese currently exceed 1 million birds in each of the Mississippi and Atlantic flyways (United States [U. S.] Fish and Wildlife Service $2007 *$ ), the potential problems with survey efforts and impacts to habitat could be substantial.

Temperate-nesting Canada Geese also are of concern within their breeding range, where they often occur in areas with few natural predators. Because of their relatively high survival and stable reproductive rates, local flocks can rapidly reach nuisance levels in urban areas and rural areas with low harvest pressure. Given that some unsuccessful breeders undergo a molt migration, we reasoned that deliberate nest destruction late in the incubation period, to ensure nest failure, would induce these birds to molt migrate. This procedure has the potential to reduce annual recruitment of young into the population, lessen the number of adults and young residing in local areas during the summer, and expose this component of the population to hunting pressure in other regions when they return in the fall. Our objective was to assess both the efficacy of this technique and to monitor the resultant timing, locations, and extent of molt-migration movements as they relate to management of AFRP Canada Geese in the Atlantic Flyway.

\section{Methods}

In 2001, eight female Canada Geese were captured at four locations in New York during late May (Table 1). Nests of five birds were destroyed during the last 7-10 days of incubation; no nests were detected for three of the eight (Table 1). Each goose was fitted with a $30 \mathrm{~g}$ satellite-tracked transmitter (PTT Model 100, Microwave Telemetry, Inc., Columbia, Maryland; mention of trade names or commercial products does not constitute endorsement or recommendation for use by the U.S. Government) attached dorsally with a harness constructed of Teflon ribbon. Transmitters had specifications for $\sim 480$ hours of battery life and were programmed to transmit for an eight-hour period every four days. Expected battery life was about eight months.

We expanded the study in 2002 to include 19 nesting females captured under similar nesting conditions in
New York $(n=4)$, Pennsylvania $(n=6)$, New Jersey $(n=4)$, Massachusetts $(n=2)$, Connecticut $(n=1)$, Vermont $(n=1)$, and Maine $(n=1)$. To simplify attachment procedures and reduce costs, we switched to transmitters mounted on plastic neck collars produced by Telonics, Inc. of Mesa, Arizona. Program features were similar to those used in 2001. Unfortunately, most of the transmitters deployed in 2002 did not provide sufficient signals to the satellites to produce usable locations. The 2002 transmitters were replaced by the manufacturer and 19 nesting females were marked in 2003: New York $(n=4)$, Pennsylvania $(n=4)$, New Jersey $(n=4)$, Massachusetts $(n=2)$, Connecticut $(n=2)$, Vermont $(n=1)$, Maine $(n=1)$, and Maryland $(n=1)$ (Table 1).

Data from the radio transmitters were obtained from the Argos satellite system of the French Space Agency via a preferential tariff agreement with the U. S. Department of Commerce's National Oceanic and Atmospheric Administration. Location estimates were classified by Argos based on their estimated accuracy and the number of transmissions received from a transmitter during a satellite overpass. Location classes 3, 2, and 1 had accuracy ratings within $1000 \mathrm{~m}$. Accuracy for location class 0 was $>1000 \mathrm{~m}$, and location classes A and $\mathrm{B}$ did not receive enough transmissions during an overpass for accuracy to be estimated (Service Argos 1996*). However, Britton et al. (1999) demonstrated that poor locations (classes $0, \mathrm{~A}$, and $\mathrm{B}$ ) received from satellite transmitters ( $30 \mathrm{~g}$ ) averaged $35 \mathrm{~km}$ from the true location of the transmitter. We therefore included all locations with a classification of $3,2,1,0, \mathrm{~A}$, or B, because the accuracy of these classes was sufficient to describe large-scale movements.

Argos estimated locations by measuring the Doppler shift of the received signals, which produces two pairs of latitude and longitude coordinates from an individual satellite overpass. Argos designates the location with the better frequency continuity as the most probable location (location 1), and the alternate location is designated as the image (location 2). Examination of our data occasionally indicated that sometimes location 2 was a more probable fix than location 1 based on the flight dynamics of Canada Geese. We developed a sorting routine similar to that of Britton et al. (1999) that sequentially examined the location pairs to identify locations that appeared most probable. The initial location for each bird was the site of banding. For each subsequent pair of locations, flight speed (distance/hr) was calculated from location 1 in the previous location pair to location 1 of the next location pair. If the bird had flown $<65 \mathrm{~km} / \mathrm{hr}$ to reach both locations 1 and 2 , we selected location 1 . If the bird had flown $>65 \mathrm{~km} / \mathrm{hr}$ to reach location 1 , but $<65 \mathrm{~km} / \mathrm{hr}$ to reach location 2 , we selected location 2 . If both locations violated our $65 \mathrm{~km} / \mathrm{hr}$ rule, we deleted both. We retained all locations with an accuracy classification of 3,2 , and 1 . When an 8-hour transmission period contained only locations with a classification of $0, \mathrm{~A}$, and $\mathrm{B}$, we esti- 
mated one location for that period as the centroid of the most probable latitude and longitude coordinates.

During the course of our study, we hypothesized that the differential propensity to undergo a molt migration could be related to genetic differences among geese from interior and coastal areas comprising our sample. In 2004, we attempted to test this by collecting blood samples from molting adult geese with young in rural areas of central New York $(n=15)$ and Pennsylvania $(n=15)$ and compared these with similarly collected samples from more coastal and urban/suburban areas of Long Island, New York $(n=5)$, New Jersey $(n=15)$, Massachusetts $(n=5)$, and Connecticut $(n=5)$. Genetic testing of microsatellite markers and mitochondrial DNA was done using methods described by Scribner et al. (2003a).

We used seven microsatellite loci that have previously been described for Canada Geese for other populations across North America (Scribner et al. 2003a, 2003b). Loci included TTU-CG-1, TTU-CG-5 (Cathey

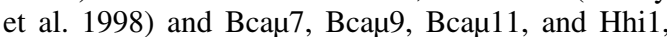
(Buchhollz et al. 1998), and CRG (Baker, unpublished data). After electrophoresis on denaturing $6 \%$ acrylamide gels, PCR products were visualized using an FMBIO II laser scanner (Hitachi Software Engineering Co., Alameda, California). Genotypes were scored based on 20 base-pair standards and reference samples of known allelic size.

We obtained sequence information from $\mathrm{a} \approx 385$ basepair (bp) fragment of the 5' end of the Canada Goose mitochondrial DNA control region using primers and conditions described in Pearce et al. (2000). Sequencing was performed using a SequiTherm Excel DNA sequencing kit (Epicentre, Inc.), following product protocols for use of fluorescently labeled primers. Sequences were aligned manually.

We estimated degree of differentiation in allele and haplotype frequency between Canada Geese sampled from coastal and interior regions using a Fisher's exact test in program GENEPOP and using F-statistics (Weir 1996) using the program F-STAT (Goudet 1995). Measures of inter-population variance in allele frequency were summarized as pair-wise estimates of population $\mathrm{F}_{\mathrm{st}}$. Significance of mean $\mathrm{F}_{\mathrm{st}}$ values (across the seven loci) were determined by jack-knifing procedures (Weir 1996). Analyses of population differences in mtDNA haplotype frequency were conducted using an analysis of molecular variance (Excoffier et al. 1992).

\section{Results}

Of the eight birds marked in New York in 2001, seven made molt migrations to areas in Quebec, Canada: four traveled to the eastern coast of Hudson Bay $\left(58^{\circ} 12^{\prime} \mathrm{N}, 76^{\circ} 60^{\prime} \mathrm{W}\right)$, two went to lowland areas east of James Bay $\left(53^{\circ} 30^{\prime} \mathrm{N}, 79^{\circ} 02^{\prime} \mathrm{W}\right)$, and one moved to an interior location $\sim 350 \mathrm{~km}$ southwest of Ungava Bay $\left(56^{\circ} 06^{\prime} \mathrm{N}, 70^{\circ} 04^{\prime} \mathrm{W}\right)$ (Figure 1). Locations from four transmitters deployed in 2002 (two from Pennsylvania,
TABLE 1. Bird identification numbers, state and year of banding (cohort), latitude and longitude of banding location, and approximate distance between banding and molting location $(\mathrm{km})$. Females with no nest are identified with an $(*)$.

\begin{tabular}{|c|c|c|c|c|}
\hline \multirow[b]{2}{*}{ ID } & \multirow[b]{2}{*}{ Cohort } & \multicolumn{2}{|c|}{ Banding location } & \multirow[b]{2}{*}{$\mathrm{km}$} \\
\hline & & latitude & longitude & \\
\hline 33115 & NY-2001 & $43^{\circ} 06^{\prime} \mathrm{N}$ & $78^{\circ} 30^{\prime} \mathrm{W}$ & 1122 \\
\hline $33116^{*}$ & NY-2001 & $43^{\circ} 06^{\prime} \mathrm{N}$ & $78^{\circ} 24^{\prime} \mathrm{W}$ & 897 \\
\hline 33117 & NY-2001 & $42^{\circ} 12^{\prime} \mathrm{N}$ & $78^{\circ} 54^{\prime} \mathrm{W}$ & 1830 \\
\hline 33118 & NY-2001 & $42^{\circ} 06^{\prime} \mathrm{N}$ & $78^{\circ} 36^{\prime} \mathrm{W}$ & 1295 \\
\hline $33119 *$ & NY-2001 & $41^{\circ} 36^{\prime} \mathrm{N}$ & $74^{\circ} 06^{\prime} \mathrm{W}$ & 1641 \\
\hline 33120 & NY-2001 & $41^{\circ} 36^{\prime} \mathrm{N}$ & $74^{\circ} 06^{\prime} \mathrm{W}$ & $\leq 60$ \\
\hline $33121 *$ & NY-2001 & $42^{\circ} 42^{\prime} \mathrm{N}$ & $75^{\circ} 30^{\prime} \mathrm{W}$ & 1941 \\
\hline 33122 & NY-2001 & $42^{\circ} 42^{\prime} \mathrm{N}$ & $75^{\circ} 30^{\prime} \mathrm{W}$ & 1725 \\
\hline 19873 & CT-2003 & $41^{\circ} 20^{\prime} \mathrm{N}$ & $71^{\circ} 32^{\prime} \mathrm{W}$ & $\leq 60$ \\
\hline 19874 & PA-2003 & $40^{\circ} 39^{\prime} \mathrm{N}$ & $77^{\circ} 45^{\prime} \mathrm{W}$ & 1830 \\
\hline 19875 & MD-2003 & $38^{\circ} 35^{\prime} \mathrm{N}$ & $76^{\circ} 07^{\prime} \mathrm{W}$ & $\leq 60$ \\
\hline 19876 & CT-2003 & $41^{\circ} 32^{\prime} \mathrm{N}$ & $73^{\circ} 04^{\prime} \mathrm{W}$ & $\leq 60$ \\
\hline 19909 & ME-2003 & $44^{\circ} 43^{\prime} \mathrm{N}$ & $68^{\circ} 54^{\prime} \mathrm{W}$ & $\leq 60$ \\
\hline 19911 & MA-2003 & $41^{\circ} 37^{\prime} \mathrm{N}$ & $71^{\circ} 06^{\prime} \mathrm{W}$ & $\leq 60$ \\
\hline 19916 & MA-2003 & $41^{\circ} 17^{\prime} \mathrm{N}$ & $71^{\circ} 27^{\prime} \mathrm{W}$ & $\leq 60$ \\
\hline 19922 & NJ-2003 & $40^{\circ} 42^{\prime} \mathrm{N}$ & $74^{\circ} 30^{\prime} \mathrm{W}$ & $\leq 60$ \\
\hline 19923 & NJ-2003 & $40^{\circ} 25^{\prime} \mathrm{N}$ & $74^{\circ} 29^{\prime} \mathrm{W}$ & $\leq 60$ \\
\hline 19930 & NJ-2003 & $39^{\circ} 35^{\prime} \mathrm{N}$ & $75^{\circ} 29^{\prime} \mathrm{W}$ & $\leq 60$ \\
\hline 19932 & NJ-2003 & $41^{\circ} 00^{\prime} \mathrm{N}$ & $74^{\circ} 09^{\prime} \mathrm{W}$ & $\leq 60$ \\
\hline 19934 & NY-2003 & $41^{\circ} 05^{\prime} \mathrm{N}$ & $73^{\circ} 51^{\prime} \mathrm{W}$ & $\leq 60$ \\
\hline 19940 & NY-2003 & $42^{\circ} 50^{\prime} \mathrm{N}$ & $73^{\circ} 50^{\prime} \mathrm{W}$ & 1573 \\
\hline 19955 & NY-2003 & $40^{\circ} 45^{\prime} \mathrm{N}$ & $73^{\circ} 07^{\prime} \mathrm{W}$ & $\leq 60$ \\
\hline 19957 & NY-2003 & $40^{\circ} 37^{\prime} \mathrm{N}$ & $73^{\circ} 15^{\prime} \mathrm{W}$ & $\leq 60$ \\
\hline 19962 & PA-2003 & $39^{\circ} 48^{\prime} \mathrm{N}$ & $80^{\circ} 03^{\prime} \mathrm{W}$ & 1396 \\
\hline 19973 & PA-2003 & $40^{\circ} 07^{\prime} \mathrm{N}$ & $72^{\circ} 24^{\prime} \mathrm{W}$ & 564 \\
\hline 19978 & PA-2003 & $40^{\circ} 32^{\prime} \mathrm{N}$ & $75^{\circ} 95^{\prime} \mathrm{W}$ & $\leq 60$ \\
\hline 20024 & PA-2003 & $40^{\circ} 36^{\prime} \mathrm{N}$ & $80^{\circ} 00^{\prime} \mathrm{W}$ & $\leq 60$ \\
\hline 20036 & PA-2003 & $42^{\circ} 09^{\prime} \mathrm{N}$ & $80^{\circ} 02^{\prime} \mathrm{W}$ & $\leq 60$ \\
\hline 20043 & PA-2003 & $41^{\circ} 15^{\prime} \mathrm{N}$ & $75^{\circ} 18^{\prime} \mathrm{W}$ & $\leq 60$ \\
\hline 20059 & VT-2003 & $44^{\circ} 05^{\prime} \mathrm{N}$ & $73^{\circ} 20^{\prime} \mathrm{W}$ & 1521 \\
\hline
\end{tabular}

$\mathrm{NY}=$ New York, $\mathrm{CT}=$ Connecticut, $\mathrm{PA}=$ Pennsylvania, $\mathrm{MD}=$ Maryland, $\mathrm{ME}=$ Maine, $\mathrm{MA}=$ Massachusetts, $\mathrm{NJ}=$ New Jersey, VT = Vermont

one from New York, and one from Vermont) suggested that these birds also made a molt migration to northern Quebec; however, the data were not sufficient to identify migration timing or provide reliable locations.

Only five of the 19 birds marked in 2003 made molt migrations to northern Quebec (three from Pennsylvania, one from New York, and one from Vermont). Three traveled to the eastern coast of Hudson Bay $\left(58^{\circ} 12^{\prime} \mathrm{N}\right.$, $\left.76^{\circ} 60^{\prime} \mathrm{W}\right)$, one went to eastern James Bay $\left(53^{\circ} 54^{\prime} \mathrm{N}\right.$, $\left.79^{\circ} 00^{\prime} \mathrm{W}\right)$, and one moved to an interior location south of Ungava Bay $\left(57^{\circ} 00^{\prime} \mathrm{N}, 7^{\circ} 36^{\prime} \mathrm{W}\right)$ (Figure 1). The 14 females that did not make a molt migration exhibited little movement during June through early November; movement of these geese was limited to within $60 \mathrm{~km}$ of the banding site. All of the birds that did not make a molt migration were from more coastal regions of the flyway (Figure 2).

Molt migrations in both 2001 and 2003 occurred in June. Marked geese that molt migrated $(n=12)$ were located in the U.S. as late as 30 May - 20 June. They arrived at terminal locations in northern Quebec (Fig- 
ure 1) between 9 and 26 June. Fall migration of these molt migrants occurred primarily in September. Birds were located in northern Quebec as late as 28 August - 29 September. They arrived in southern Canada or the U.S. between 6 September and 3 October (Figure 3 ). There was no distinguishable difference in timing of molt and fall migrations between marked geese in 2001 and 2003. Molt migrations ranged in distance from 564 - $1941 \mathrm{~km}$ (Table 1).

Genetic analysis of the two groups of geese showed no evidence across loci of significant differences in microsatellite allele frequency $(F=0.005, P>0.05)$. Likewise, analysis of variance results for mtDNA haplotype frequencies also revealed no evidence of significant differences between the two groups $(\Phi=0.00$, $P>0.40$ ). When analyses were extended to include reference samples from the two subarctic-nesting Canada Goose populations (AP and NAP), we observed differences in allele frequencies among all three populations for both microsatellite loci and mtDNA haplotype ( $P<0.05$ for both markers $)$.

\section{Discussion}

Our results provide convincing evidence of the movement of some molting AFRP geese to the northern breeding ground of AP geese at a critical time during the spring population monitoring and summer prehunting season banding periods. Zicus (1981) and Lawrence et al. (1998), working with temperate-breeding Canada Geese in Wisconsin and Illinois, each reported $50-60 \%$ of their spring population departing on molt migrations. Mykut (2002) satellite-tracked female Canada Geese in Michigan, whose nests were destroyed, as in this study, late in incubation. He found $62 \%(n=37)$ in 2000 and $73 \%(n=52)$ in 2001 of these birds molt-migrating to James and Hudson Bays in northern Canada. The literature is replete with other reports of long distance molt migrations in temperatenesting geese.

The propensity to molt migrate, observed in nestfailed females from rural New York and Pennsylvania, but not for birds nesting in more coastal areas of the flyway, prompted us to suspect a possible genetic difference resulting from regional differences in the origin of these birds. Blandin and Heusmann (1974) reported that geese breeding in eastern Massachusetts were of mixed racial stock, nonmigratory in nature, and the progeny of decoy birds released in the late 1930s. Morphometric measurements of these birds (Pottie and Heusmann 1979) indicated a probable mixing of several sub-species, in which B. c. maxima (Giant Canada Goose) predominated. In contrast, geese in rural New York and Pennsylvania are primarily large Canada Geese of the B. c. maxima and B. c. moffitti (Great Basin Canada Goose) stock introduced after the 1950s to areas previously devoid of breeding geese. These birds may be more similar to mid-continent temperatenesting populations of restored or reintroduced giant
Canada Geese. Molt migration in giant Canada Geese is considered a common behavior (Abraham et al. 1999). We were able to detect genetic differences of sufficient magnitude to discern the AFRP geese we sampled from subarctic-nesting populations of geese occurring in the flyway (AP and NAP), but we did not detect genetic differences between the two regional cohorts sampled within the AFRP.

Two factors favoring movement of waterfowl to remote regions to molt are the reduced risk to survival and greater food availability (Hohman et al. 1992; Baldassarre and Bolen 2006). In Canada Geese, successful breeders also are often behaviorally dominant over nonbreeders (Raveling 1970), which may influence movement of the nonbreeding segment away from nesting areas. However, in New Jersey, Nichols et al. (2004) estimated that only $22-31 \%$ of resident Canada Geese migrated out of the state to molt. They suggested that birds in and near urban-suburban dominated landscapes may have many suitable molting sites consisting of large expanses of lush, fertilized lawns interspersed with water bodies and few predators. The gathering of nonbreeders into larger flocks to molt on or near breeding areas may also lessen stress associated with behavioral interactions of adults with young. Lawrence et al. (1998) also noted that in more recent times, with greater emphasis on hunting of temperatenesting geese to manage their numbers, birds leaving the sanctuary of local breeding areas are more likely to be harvested.

The coastal region of our study, from which molt migration did not occur (Connecticut, Massachusetts, Maryland, and New Jersey), contains $21 \%$ ( $N=$ 245351) of the AFRP spring population estimate (United States Fish and Wildlife Service 2007*) in the U.S. Geese in New York, Pennsylvania, and Vermont make up $\sim 5 \%(N=514181)$ and the coastal states of Delaware and Virginia, where geese were not sampled as part of this study, comprise $\sim 14 \%(N=163655)$. If we assume that $50 \%$ of the geese in New York and Pennsylvania are molt migrant non-breeders or unsuccessful breeders (Zicus 1981; Lawrence et al. 1998), then the potential exists for a substantial movement of geese ( $\geq 250000$ ) to subarctic breeding areas in northern Canada. This number is further increased by temperate-nesting birds moving into subarctic regions from the Mississippi Flyway.

The population estimate for AP geese in northern Quebec, where we suspect most AFRP birds molt migrate to, is $\sim 1.2$ million (Harvey and Rodrique $2007 *$ ). However, the authors caution that differences in survey timing and the abundance of molt migrants can clearly introduce substantial variability in the total population estimate. Similar conflicts are reported by Abraham et al. (1999) for Southern James Bay Population Canada Geese in northern Ontario. Spring surveys of AP geese are timed to cover the mid to late incubation period; generally the last two weeks in June. Arrival of AFRP 


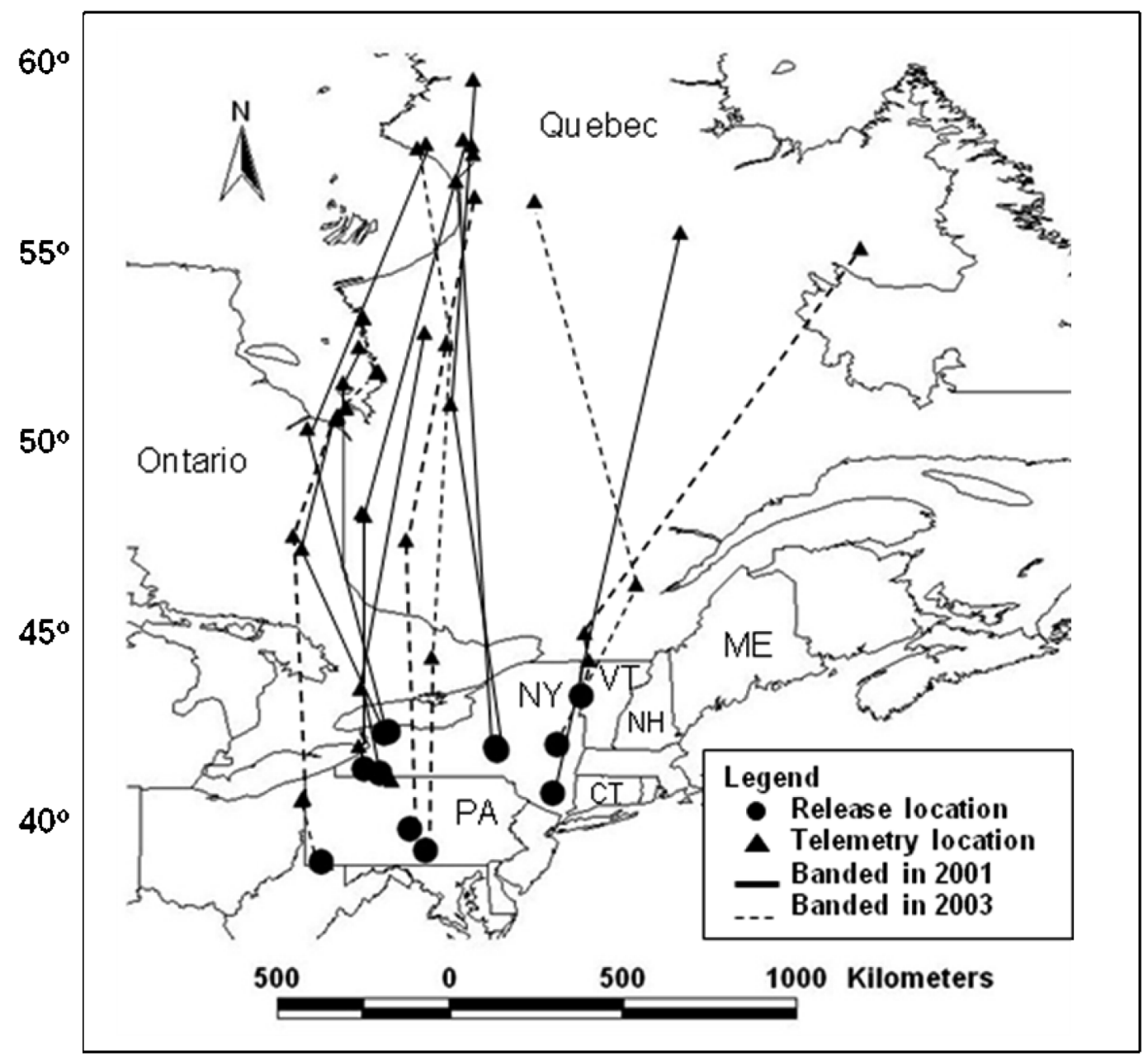

FIgURE 1. Locations of Atlantic Flyway Resident Population Canada Geese during spring molt migration in 2001 and 2003. Locations were identified using birds marked with satellite-tracked transmitters. Birds arrived at terminal molting areas in northern Quebec between 9 June and 16 June.

molt-migrants coincides very closely with the beginning of these surveys. Similarly, summer banding of AP geese, which usually takes place in late July early August, also occurs when molt migrants are still on the AP breeding grounds. Given that molting large Canada Geese can require up to 40 days to obtain the $85 \%$ of primary feather development required to regain flight (Hanson 1965), geese arriving in mid-June have the potential still to be flightless when subarctic-breeding adults with young are being banded. This mixing of populations re-enforces the need to (1) monitor the status of subarctic-breeding populations using numbers of breeding pairs surveyed, rather than total counts involving groups of geese of unknown origin, and (2) band only flightless adults with young during the summer pre-season banding period to ensure a representative sample of subarcticnesting populations of Canada Geese.

In the late 1980s, as an aid in the control of increasing numbers of temperate-nesting geese, the U.S. Fish and Wildlife Service endorsed the implementation of special hunting seasons in September and late-winter, when subarctic-nesting goose populations would be less likely affected (Heusmann et al. 1998). While effective in many rural areas, geese in urban and suburban environments often receive little exposure to hunter harvest (Smith et al. 1999). Efforts to control nuisance geese generally rely on non-lethal methods involving addling and oiling of eggs in nests (Christens et al. 1995) and harassment techniques to move birds from heavily used residential and industrial areas (Holevinski et al. 2007). Both methods provide only a moderate degree of relief, at best. 


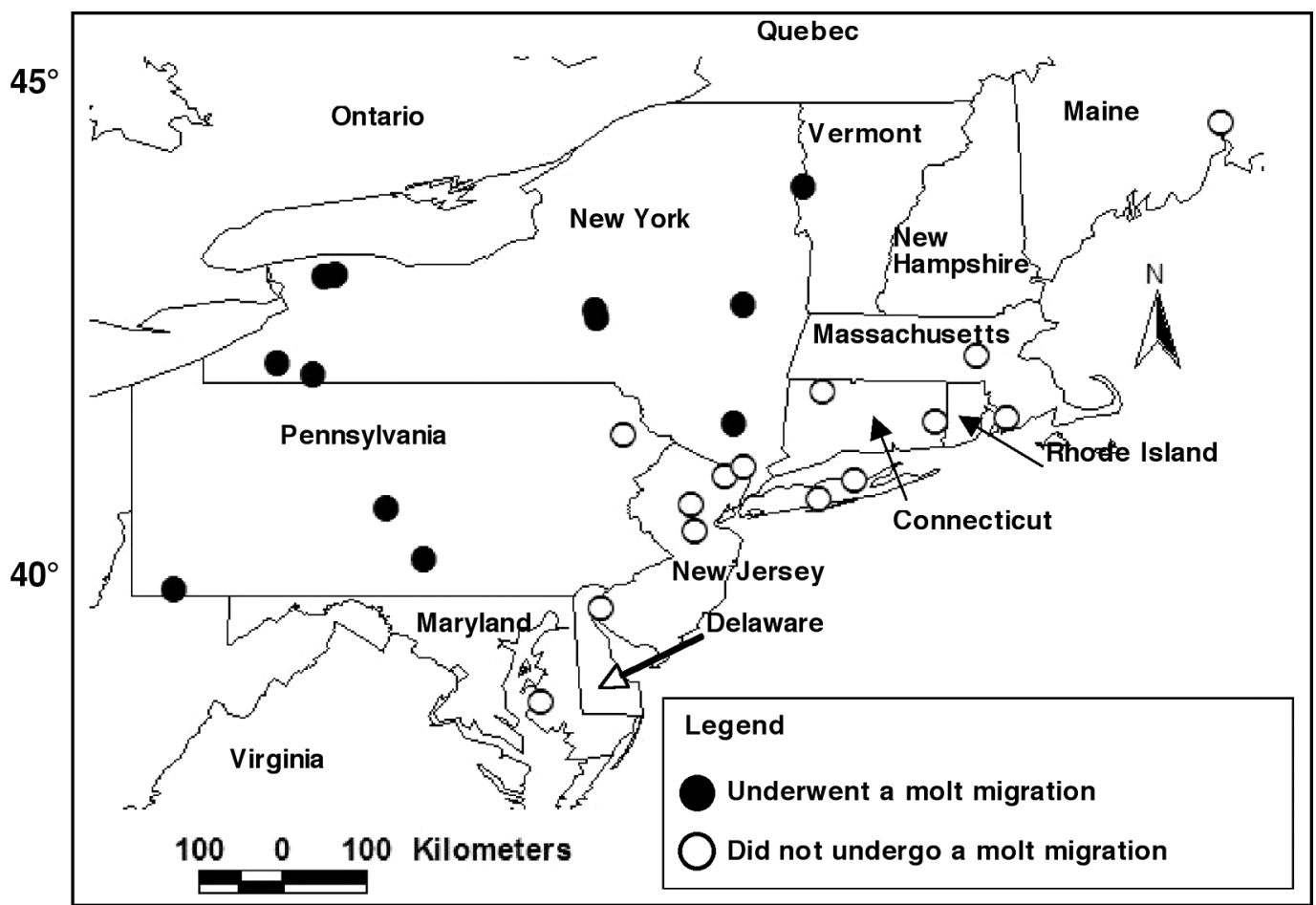

Figure 2. Banding locations of Atlantic Flyway Resident Population Canada Geese marked with satellitetracked transmitters during May 2001 and 2003.

Many studies have demonstrated that altering survival of adult geese is much more effective in changing population size than altering recruitment rates (Trost et al. 1986; Schmutz et al. 1997). However, direct culling of molting birds continues to remain a socially unacceptable option for population control in many areas. One alternative, transplanting flightless adults with young from nuisance areas to rural areas prior to the fall hunting season, successfully reduced survival of adults in comparison to non-transported birds, but was both time consuming and costly (Holevinski et al. 2006). Inducing molt migration of adult breeding geese by destroying nests late in incubation, as demonstrated in this study, showed potential for both removal of birds from their breeding area during the spring and summer period and exposing them to hunting outside the region. However, our failure to demonstrate this in coastal areas, which have more prominent nuisance Canada goose issues, was problematic. We can only assume that the reason for this was attributed to the historical origin of captive-reared birds of mixed subspecies making up AFRP flocks in this part of the flyway and the availability of quality local molting habitat distinct from brood-rearing areas.

\section{Acknowledgments}

We acknowledge the valuable assistance and funding received from the following individuals and their respective agencies: P. Castelli and T. Nichols, New Jersey Division of Fish and Wildlife; H. W. Heusmann, Massachusetts Division of Fisheries and Wildlife; M. Huang, Connecticut Department of Environmental Protection; W. Crenshaw, Vermont Fish and Wildlife Department; B. Allen, Maine Department of Inland Fisheries and Wildlife; L. Hindman, Maryland Wildlife and Heritage Service; and the agencies and university affiliates of the authors. Valuable editorial comments were provided by G. Baldassarre, College of Environmental Science and Forestry at Syracuse University, L. Hindman, and the anonymous referees for this journal.

Documents Cited (marked $*$ in text)

Atlantic Flyway Waterfowl Council. 1999. Atlantic Flyway Resident Canada Goose Management Plan. Canada Goose Committee, Atlantic Flyway Council, Laurel, Maryland, USA.

Harvey, W. F., and J. Rodrique. 2007. A breeding pair survey of Canada Geese in northern Quebec - 2007. Unpublished Report, Atlantic Flyway Waterfowl Council, Laurel, Maryland, USA. 


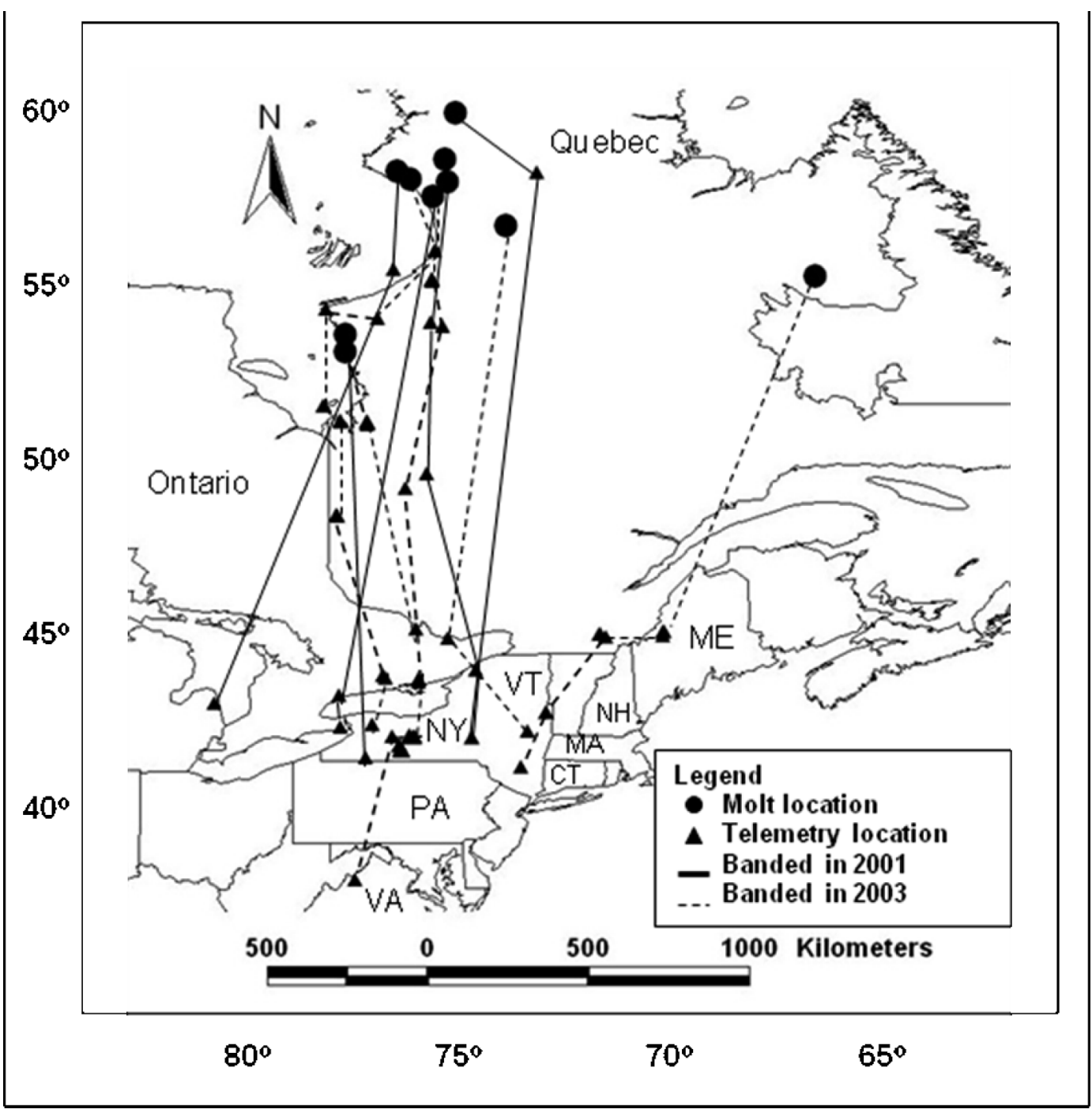

Figure 3. Locations of Atlantic Flyway Resident Population Canada Geese returning from molting locations in the fall 2001 and 2003. Locations were identified using birds marked with satellite-tracked transmitters. Birds initiated fall migration between 28 August and 29 September.

Service Argos. 1996. User Manual. Landover, Maryland, USA.

U. S. Fish and Wildlife Service. 2007. Waterfowl population status: 2007. Unpublished report, U.S. Fish and Wildlife Service, Washington, D.C., USA.

\section{Literature Cited}

Abraham, K. F., J. O. Leafloor, and D. H. Rusch. 1999. Molt migrant Canada geese in northern Ontario and western James Bay. Journal of Wildlife Management 63: 649655 .
Baldassarre, G. A., and E. G. Bolen. 2006. Waterfowl ecology and management. Krieger Publishing Company, Malabar, Florida, USA.

Blandin, W. W., and H. W. Heusmann. 1974. Establishment of Canada Goose populations through urban gosling transplants. Transactions of the Northeast Fish and Wildlife Conference 31: 83-100.

Britton, M. W., P. L. Kennedy, and S. Ambrose. 1999. Performance and accuracy evaluation of small satellite transmitters. Journal of Wildlife Management 63: 13491358. 
Buchholtz, W., J. M. Pearce, B. J. Pierson, and K. T. Scribner. 1998. Dinucleotide repeat polymorphisms in waterfowl (family Anatidae): characterization of a sex-linked (z-specific) and 14 bi-parentally inherited loci. Animal Genetics 29: 323-325.

Cathey, J. C., J. A. Dewoody, and L. M. Smith. 1998. Microsatellite markers in Canada Geese (Branta canadensis). Journal of Heredity 89: 173-174.

Christens, E. H., H. Blokpoel, G. Ranson, and S. W. D. Jarvie. 1995. Spraying white mineral oil on Canada goose eggs to prevent hatching. Wildlife Society Bulletin 23: 228-230.

Davis, R. A., R. N. Jones, C. D. MacInnes, and A. J. Pakulak. 1985. Molt migration of large Canada Geese on the west coast of Hudson Bay. Wilson Bulletin 97: 296-305.

Excoffier, L., P. E. Smouse, and J. M. Quattro. 1992. Analysis of molecular variance inferred from metric distances among DNA haplotypes: application to human mitochondrial DNA restriction data. Genetics 131: 479-491.

Goudet, J. 1995. FSTAT (version 1.2): a computer program to calculate F-statistics. Journal of Heredity 86: 485-486.

Hanson, H. C. 1965. The giant Canada Goose. Southern Illinois University Press, Carbondale, Illinois, USA.

Heusmann, H. W., T. E. Early, and R. G. Burrell. 1998. Experimental late Canada Goose season in Massachusetts. Pages 121-126 in Biology and management of Canada Geese. Edited by D. H. Rusch, M. D. Samuel, D. D. Humburg, and B. D. Sullivan. Proceedings of the International Canada Goose Symposium, Milwaukee, Wisconsin, USA.

Hohman, W. L., C. D. Ankney, and D. H. Gordon. 1992. Ecology and management postbreeding waterfowl. Pages 128-189 in Ecology and management of breeding waterfowl. Edited by B. D. J. Batt, A. D. Afton, M. G. Anderson, C. D. Ankney, D. H. Johnson, J. A. Kadlec, and G. L. Krapu. University of Minnesota Press, Minneapolis, USA.

Holevinski, R. A., P. D. Curtis, and R. A. Malecki. 2007. Hazing of Canada geese is unlikely to reduce nuisance populations in urban and suburban communities. Journal of Human-Wildlife Conflicts 1(2): 257-264.

Holevinski, R. A., R. A. Malecki, and P. D. Curtis. 2006. Can hunting of translocated nuisance Canada geese reduce local conflicts? Wildlife Society Bulletin 34: 845-849.

Lawrence, J. S., G. A. Perkins, D. D. Thornburg, R. A. Williamson, and W. D. Klimstra. 1998. Molt migration of giant Canada Geese from west-central Illinois. Pages 105-111 in Biology and Management of Canada Geese. Edited by D. H. Rusch, M. D. Samuel, D. D. Humburg, and B. D. Sullivan. Proceedings of the International Canada Goose Symposium, Milwaukee, Wisconsin, USA.

Mykut, R. C. 2002. Evaluating satellite and conventional VHF telemetry to document molt migration of giant Canada Geese (Branta canadensis maxima) from southeastern Michigan. PhD thesis, Michigan State University, Lansing, USA.

Mykut, R. C., H. H. Prince, and D. R. Luukkonen. 2004. Evaluating satellite and conventional radiotelemetry to document molt migration of giant Canada Geese from southern Michigan. Pages 203-211 in Proceedings of the 2003
International Canada Goose Symposium. Edited by T. J. Moser, R. D. Lien, K. C. VerCauteren, K. F. Abraham, D. E. Andersen, J. G. Bruggink, J. M Coluccy, D. A. Graber, J. O. Leafloor, D. R. Luukkonen, and R. E. Trost. Madison, Wisconsin, USA

Nichols, T. C., N. L. Zimpfer, R. V. Raftovich, and P. M. Castelli. 2004. Molt migration of New Jersey resident Canada Geese. Pages 169-177 in Proceedings of the 2003 International Canada Goose Symposium. Edited by T. J. Moser, R. D. Lien, K. C. VerCauteren, K. F. Abraham, D. E. Andersen, J. G. Bruggink, J. M Coluccy, D. A. Graber, J. O. Leafloor, D. R. Luukkonen, and R. E. Trost. Madison, Wisconsin, USA

Pearce, J. M., B. J. Pierson, S. L. Talbot, D. V. Derksen, D. Kraege, and K. T. Scribner. 2000. A genetic evaluation of morphology used to identify hunter-harvested Canada geese. Journal of Wildlife Management 64: 863-874.

Pottie, J. J., and H. W. Heusmann. 1979. Taxonomy of resident Canada Geese in Massachusetts. Transactions of the Northeast Fish and Wildlife Conference 36:132-137.

Raveling, D. G. 1970. Dominance relationships and agonistic behavior of Canada geese in winter. Behavior 37: 291-317.

Salomonsen, F. 1968. The moult migration. Wildlfowl 19: $5-24$.

Schmutz, J. A., R. F. Rockwell, and M. R. Petersen. 1997. Relative effects of survival and reproduction on the population dynamics of Emperor geese. Journal of Wildlife Management 61: 191-201.

Scribner, K. T., R. A. Malecki, B. D. J. Batt, R. L. Inman, S. Libants, and H. H. Prince. 2003a. Identification of source population for Greenland Canada geese: Genetic assessment of a recent colonization. The Condor 105: 771782.

Scribner, K. T., S. L. Talbot, J. M. Pearce, B. J. Pierson, K. S. Bollinger, and D. V. Derksen. 2003b. Phylogeography of Canada Geese (Branta canadensis) in western North America. Auk. 120: 889-907.

Smith, A. E., S. R. Craven, and P. D. Curtis. 1999. Managing Canada Geese in urban environments. Jack Berryman Institute Publication 16, and Cornell University Cooperative Extension, Ithaca, New York, USA.

Sterling, R. T., and A. Dzubin. 1967. Canada goose moult migration to the Northwest Territories. Transactions of the North American Wildlife and Natural Resources Conference 31: 355-373.

Trost, R. E., R. A., Malecki, L. J. Hindman, and D. C. Luszcz. 1986. Survival and recovery rates of Canada geese from Maryland and North Carolina. Proceedings of the Annual Conference of Southeastern Association of Fish and Wildlife Agencies 40: 454-464.

Weir, B. S. 1996. Genetic Data Analysis II. Sinauer and Associates, Sunderland, Massachussetts, USA.

Zicus, M. C. 1981. Molt migration of Canada geese from Crex Meadows, Wisconsin. Journal of Wildlife Management 45: 54-63.

Received 8 August 2006

Accepted 7 May 2008 